\title{
LANGUAGE INTERFERENCE IN ELT WRITING CLASS
}

\author{
Muliyana1, Muhammad Zuhri Dj*2., Andi Muhammad Yauri $^{3}$ \\ 1,2,3 Department of English Education, Institut Agama Islam Negeri Bone, Indonesia \\ *Corresponding Author Email: @zuhristaindije@gmail.com
}

\begin{abstract}
This research about The Effect of Using Language Interference in ELT Writing Class at The Tenth Grade of Athirah Bone. It is intended to find out two problems of writing. The first problem is the types of errors made by the students in students' writing skills of the tenth grade of Athirah Bone. This research used a qualitative method by implementing interview. The sample consisted of 9 students from Athirah Bone. The result shows that the students' perception of the types of students' errors in writing consist of five perceptions. The first is students' perceptions relate to the feeling. The second is students' perceptions relate with the first language' influence students in mastering the second language. The third is the students' perception relates to the students' experiences and kinds of interferences that students have made on writing. The fourth is the students' perception relates to the factors that cause students to do interfere in writing. The last is about the students' perception of the difficulties in writing. The second problem is the factors that cause students to do interfere in writing through the observation, it is found that there are four factors that make the students of the tenth grade of Athirah Bone do interfere in writing. The first is do not master spelling. The second is still confused about using the article. The third is Missing using singular and plural nouns. The last is missing space.
\end{abstract}

Key Words: Language Interference 1; ELT Writing Class 2

\section{INTRODUCTION}

One of the language skills that have to be mastered by students in learning a foreign language like English is writing. Writing can appear as a problematic topic to study for students as multilingual, especially in mastering the foreign language. Writing is one of the basic skills of the English language. It is generally considered one of the most difficult rather than reading, listening, and speaking for foreign language students.

The writing was frequently useful as preparation for some other activities (Harmer, 2007:33). Writing could express what people's ideas well; however, to make strong meaning, interesting and clear for the reader, the writer should practice a lot. Realize how important writing is for learners, every student needs to develop it.

According to Mayers (2003:2) explains that writing is categorized as a productive skill and described as a skill that had many exercises to be developed. However writing is not completely gifted skill. It means that the ability of writing can be achieved through many repetitions, trials and errors, and reinforcement.

Writing is considered as a difficult activity for the students to learn. Many students get stuck when they have to express their thought in writing because they must think about the content and the syntactic structure in the second language. These are considered as factors that cause the difficulty of writing. The difficulty in generating the text and expressing the ideas into written text maybe because of students' limitedness of language competence in the target language. Nunan (1991) also add that students need to think about the appropriate lexical and syntactic choices. As a result, students tend to take an instant way to make good writing. When students are asked to write by their teacher, they often directly transfer their first language to the target language in their writing. It happens because students do not realize that the first language and the target language have distinctly different rules in constructing sentences. Consequently, errors occur as a result of this case.

There are many factors that influence the problems in learning English; one of them is because of the interference of the first language. Chaer and Agustina (1995:158) stated that Interference is the change of language system used in other elements of language which is 
IJRETAL

International Journal of Research on English Teaching and Applied Linguistics, Vol. 1, No.2, December 2020

regarded as a mistake because it deviates from the rules of the language used. Furthermore, Ellis (1997:1) stated that first language transfer refers to the influence of students' first language that exerts over the acquisition of students' target language. This influence is referred to as negative transfer or interference and believed that errors were the result of interference. The error indicates that the students' target language has interfered with their first language.

Weinreich (1968:18) asserts interference is the deviation of language norm in usage as the effect of bilingual toward another language. The interference term is firstly used by Weinreich to name the existence of a different language system spoken by bilingual speakers in using a language. Interference happens when the speaker uses a foreign language and ones which is interfered into a foreign language is the first language or mother tongue.

Nababan (1968:35) stated that interference only happens to speakers when they use a second or foreign language in their speaking or writing. It can be receipted interference (the use of the second language receipted by the elements of the first language) and productive interference (the use of the first language by using element and structure of the second language), exactly when they use both languages. A bilingual person may be said to be one who can communicate, to varying extents in a second language.

Corder (1987) stated that first language interference is the result of language habits established in the native language of the student. When the student uses English, he brings his native language habits into the target language being learned.

As EFL, country, Indonesia, English is learned as a foreign language. Learning a foreign language requires consistency in adjusting the first language form into a foreign language because both of them have a different structure. In learning foreign language learners are usually interfered with by the elements of the first language, and the students frequently make errors because they are common features of learning the new foreign or second language.

James (1998:12) stated that "lexically error" in the speech or writing of a foreign language learner means the use of a linguistic item such as a word, a grammatical item, and a speech act in a way which a fluent or native speaker of the language regards as showing faulty or incomplete learning". Generally, errors result from incomplete knowledge, whilst a mistake is made by a learner when writing or speaking which is caused by lack of attention, fatigue, carelessness, or some other aspects of performance.

Writing errors were also faced by students at the tenth grade of Atirah Bone to do writing exercises. The researcher who teaches there required them to write about something freely and then found their errors. Although they had studied basic grammar, the students still made many errors in their writings. The students of the tenth grade of Athirah Bone get difficulties in expressing their ideas in English. Almost all students often feel bewildered or even surrender while trying to write English. This can obstruct the students to make good progress in their writing ability. The problem is not only found on the beginner-level students, but also at the higher-level students. They can understand English indeed, but when they try to express their idea in writing they cannot write well. Such as, when the teacher asked the students to translate some words in English like "dokter gigi" they directly answer" Doctor teeth". The correct is" dentist" This includes an error in using a vocabulary. In spelling words, for example when they tried to translate some words in English on their writing they sometimes did an error in spelling for an example "beker", the correct is "baker". In making a sentence the students also usually make a grammatical error, for example "She borrow my pen", the students sometimes don't realize that they had made an error in the grammatical, such as they forget to put "s" at the end of the verb.

Based on what the researcher had found in the students' writing at the tenth grade of Athirah Bone that there are three error categories, they are; sentence structure, spelling, and verb form. Those categories inspired the researcher to know the errors that were caused by first language interference. 
IJRETAL

International Journal of Research on English Teaching and Applied Linguistics, Vol. 1, No.2, December 2020

In conclusion based on the reasons above the writer wants to conduct research to discover the effect of language interference in writing at the tenth grade of Athirah Bone in the academic year 2019/2020.

\section{LITERATURE REVIEW}

\section{A. Definition of Language Interference}

There are a lot of definitions to interpret what interferences are. Hanna (2009:3) stated that interference is a language produced by foreign learners/students which is influenced and even distorted by the mother tongue of the learners/students. While, Odlin (1997:3) argued that transfer or interference is the influence resulting from similarities and differences between the target language and any other language that has been previously (and perhaps imperfectly) acquired. Interference may be viewed as an adaptive strategy in which the speaker tries to speak the interlocutor's mother tongue although he has little proficiency in it.

Refer to Tarano (2006:3), the interference encompasses not just phonology, morphology, and syntax, but also the lexical, pragmatic, and discourse levels. In this study, the researcher should be research Bima language interference into the Englishlanguage, because of the language, which automatically has a dissimilar system, as well as phonology, morphology, and syntax.

Lyon (1997:4) stated that Phonology is the level at which the linguistic describe the sound system of a particular language. From the statement above, phonology is the level of linguistic that studies a sound system of language. The phonological system of a language consists of the phonemic and phonetic representation of morphemes. Language has different accents; their pronunciation differs according to the geographical location, ages, social status, and educational background. If someone utters the letters with use his dialect, so it called "interference" in the level phonology. As everybody knows, Indonesian has a sound system; for illustrating such as /banyak/ mean /many/ or /much /.

Blomfield (1995:4) argued that morphology is related to the constructions of words and parts of words. According to opinions, it can be concluding that morphology is a scientific study about word structure and formation rules. As everybody knows, in Indonesian, there is not classification plural and singular, there is a form in Bima language is the same form, but in the English language is very different. A case as follows; if the Indonesian has the word "siswa" is "student" but if the plural, "siswa- siswa" is "students".

The Syntax is a part of linguistics that is the scientific study about a rule of language. Noam Chomsky in Maniam (2010:4) sees syntax as a branch of biology/ since they conceive of syntax as the study of linguistic knowledge as embodied in the human mind. From some statements above, it can be concluding that syntax is the scientific study about grammatical and rule of language.

Based on the statements above, interference or transfer language produced by the learners which influence on their mother tongue. It occurs because of the difference between the native language and target language, because it native language and target language have their system. The mother tongue always influences in a foreign language.

\section{B. The factors of language Interference}

There are three factors that cause language interference as follow:

a. The interlingual factor. Interlingual transfer is a significant source for language learners. This concept comes from constructive analysis of the behavioristic school of 
IJRETAL

International Journal of Research on English Teaching and Applied Linguistics, Vol. 1, No.2, December 2020

learning. It stresses upon the negative interference of mother tongue as the only source of errors. The construction 'I like to read 'is uttered as 'I read to like' by many Hindi Speakers. In Hindi, the verb is pre-positioned while in English it is post positioned. This type of error is the result of negative transfer of first language rules to target language system.

The over Extension of analogy. Usually, a learner has been wrong in using a vocabulary caused by the similarity of the element between first language and second language, e. $g$ the use of cognate word (the same form of word in two languages with different functions or meanings). The example is the using of month and moon. Indonesian learners may make a mistake by using month to say moon in the space.

b. Transfer of structure. There are two types of transfer according to Dulay et.al (1982:101), positive transfer and negative transfer. Negative transfer refers to those instances of transfer, which result in error because old habitual behavior is different from the new behavior being learned. On the contrary, positive transfer is the correct utterance, because both the first language and second language have the same structure, while the negative transfer from the native language is called interference.

\section{The examples of Interference}

1. Phonology

Such as, "Mbak, boleh minta password 'way-fi'nya?"

"maaf mas Wi-fi di kantor ini sedang dalam perbaikan?"

The correct pronunciation of"Wi-fi' is "way-fay".

2. Morphology

Such as, in Indonesia sometimes we meet with our friends and say"

jaringannya tidak konnek ya?". The correct morphology is disconnecting.

3. Syntax

Such as, Lina, " Mauka otewe dulu". As a bilingual students sometimes uses this word in missing syntax in daily action by saying "OTW". The correct is "On the way ".

4. Lexicon

Such as, The teacher asked students how to say in English dokter gigi, the student directly said "doctor teeth". It includes interference in the lexicon, the correct is "dentist".

5. Semantic

Such as, Gadis itu sedang bad mood. The word" bad mood "means kurang baik.

\section{RESEARCH METHOD}

This research used qualitative research. The sample of this research is the students at the tenth grade of Athirah Bone. The total is about 78 students. In the procedure of collecting data the researcher will use an interview and observation. The researcher will research the factors that cause students to do interfere in writing through observation, and the researcher will know students' perceptions about the types of students' errors in writing through an interview. After that the researcher will analyze the data. The last, the researcher will conclude the data as a result.

The qualitative data analysis suits this research is from Miles and Huberman in Keith (2009:174-175). The approach is familiarly called 'transcendental realism' and the main 
IJRETAL

International Journal of Research on English Teaching and Applied Linguistics, Vol. 1, No.2, December 2020

components of their analysis are data reduction, data display, drawing, and verifying conclusions interacting throughout the analysis as shown in the frame above. The first is the collecting data, all the data will be collected to analyze. The second is the data will analyze through data reduction. It will occur continually throughout the analysis as the main part and can not be separated from the analysis. This analysis will happen throughout conceptualizing and explaining. The third is data display, data display, and data reduction are related, because the data that has reducted will display through many different ways of displaying data graphs, charts, network diagrams of different types, and anyway that move the analysis forward is appropriate. The last, the data will conclude, this part still relates to the data reduction and display data. This part maybe not noted early in the analysis, but they may be vague a dill-formed at this stage. They are not finalized until all the data are in, and have been analyzed.

\section{FINDING AND DISCUSSION}

\section{A. The factors cause students to do interfere in writing}

The students as the object of this research were observed by the researcher directly in the location to describe the factor cause students to do interfere in writing. The research did visibly, it means that the researcher introduced herself and her research. Based on the data that the researcher has gotten in the observation session, the researcher paid attention to the teacher when he gave material for the students, at the time teacher thought about someone's experience. The teacher used English to explain the material, after giving the material there is an interaction between the teacher and students and the teacher tried to give an assignment for them to make a history about their experiences. They studied in a group, in the session the researcher found some interferences relate with their ways to make a history, namely:

\section{Do not master spelling}

Based on the result of observation through students A and B' writings had found that there are some mistakes in spelling. They are chararacteristic, upun, vicarous, narrrative, and toentertain.

\section{a. Chararacteristic}

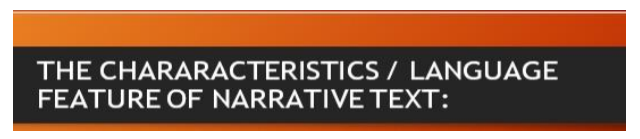

Based on the picture, it can be known that there is an incorrect spelling. That is the word "chararacteristic", Based on the dictionary the correct is "characteristic".

\section{b. Upun}

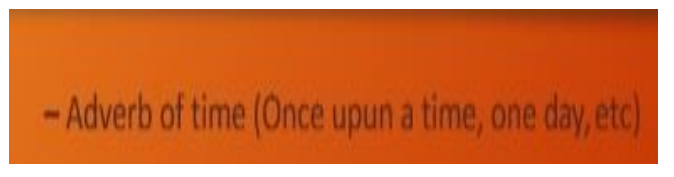

Based on the picture, it can be known that there is missing a spelling. That is the word "upun". This word has analyzed by a dictionary that is true because the correct is" upon".

\section{c. Vicarous}

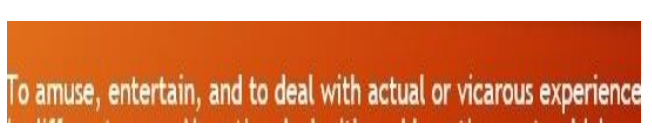

Based on the picture, had shown that there is a mistake in spelling word, that is "'Vicarous". Based on the dictionary has categorized it as incorrect spelling. So, the correct is

"Vicarious". 
IJRETAL

International Journal of Research on English Teaching and Applied Linguistics, Vol. 1, No.2, December 2020

\section{d. Narrrative}

Narrrative text is a kind of text to tell
the stoly that past tense. The pupose of
the text toentertain or to amuse the
readers or listeners about the story

Based on the picture, , it can be known that student B does miss spellings, which is "Narrrative". The correct is "Narrative".

\section{e. Toentertain}

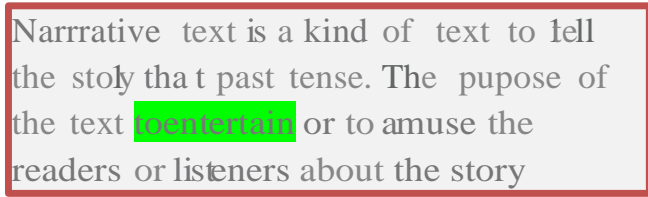

Based on the picture, it can be known that student B does misspelling, which is toentertain. The correct is to entertain.

\section{Still confused about using the article}

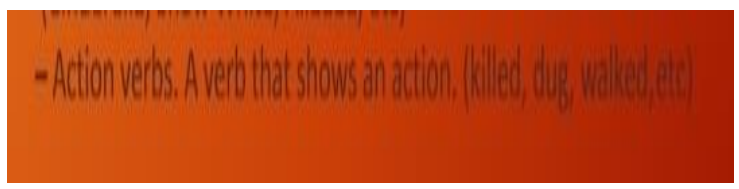

Based on the picture, it can be understood that the article "an" is put before the word "action" is inappropriate because there are some actions that shown on the data they are; killed, dug, and walked. It is better the article "an" is moved from the sentence.

\section{Missing plural noun}

Based on the result of observation through students B' writing had found that there is a mistake in using a plural noun. It is type.

\section{a. Type}

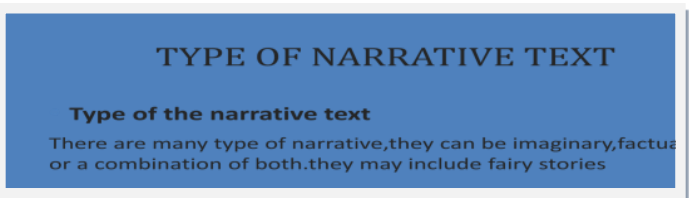

Based on the picture, it can be understood that student $\mathrm{B}$ does missing in using a plural noun. That is "type."The correct is "types".

\section{b. Missing space}

Based on the result of observation through students' writing had found that there are some missing spaces. They are factual, mysteries, science, romance, horror stories, adventure stories, fables, myths and legends, slice of life, personal experience, orientation, characteristic, complication, resolution, and coda/reorientation

\section{TYPE OF NARRATIVE TEXT}

\section{- Type of the narrative text}

There are many type of narrative,they can be imaginary,factual or a combination of both.they may include fairy stories, mysteries, science fiction, romance, horor stories,adventure stories ,fables, myths and legends,slice of life,personal experience 
IJRETAL

International Journal of Research on English Teaching and Applied Linguistics, Vol. 1, No.2, December 2020

\section{1) Factual}

Based on picture above, had shown that there is a missing space. That is factual. The correct is before the word" factual" has to put extra space.

\section{2) Mysteries}

Based on picture above, had shown that there is a missing space. That is mysteries. The correct is before the word" mysteries" has to put extra space.

\section{3) Science}

Based on picture above, had shown that there is a missing space. That is science fiction. The correct is before the word" science" has to put extra space.

\section{4) Romance}

Based on picture above, had shown that there is a missing space. That is romance. The correct is before the word" romance" has to put extra space.

\section{5) Horror stories}

Based on picture above, had shown that there is a missing space. That is horror stories. The correct is before the word" horror stories" have to put extra space.

\section{6) Adventure stories}

Based on picture above, had shown that there is a missing space. That is adventure stories. The correct is before the word" adventure stories" have to put extra space.

\section{7) Fables}

Based on picture above, had shown that there is a missing space. That is fables. The correct is before the word" fables" has to put extra space.

\section{8) Myths and legends}

Based on picture above, had shown that there is a missing space. That is myths and legends. The correct is before the word" myths and legends" have to put extra space.

\section{9) Slice of life}

Based on picture above, had shown that there is a missing space. That is a slice of life. The correct is before the word" slice of life" has to put extra space.

\section{0) Personal experience}

Based on picture above, had shown that there is a missing space. That is a personal experience. The correct is before the word" personal experience" has to put extra space.

\begin{tabular}{l} 
SRUCTURE TEXT OF NARRATIVE TEXT \\
\hline structure \\
\#Orientation : It is about the opening paragraph where the characters of the story \\
are introduced. \\
\# Complication : Where the problems in the story developed. \\
\# Resolution : Where the problems in the story is solved. \\
\# Coda / reorientation (optional) - lesson from the story
\end{tabular}


IJRETAL

International Journal of Research on English Teaching and Applied Linguistics, Vol. 1, No.2, December 2020

\section{1) Orientation}

Based on picture above, had shown that there is a missing space. That is orientation. The correct is before the word" orientation" has to put extra space.

\section{2) Characteristic}

Based on picture above, had shown that there is a missing space. That is characteristic. The correct is before the word" characteristic" has to put extra space.

\section{3) Complication}

Based on picture above, had snown that there is a missing space. That is a complication. The correct is before the word" complication" has to put extra space.

\section{4) Resolution}

Based on picture above, had shown that there is a missing space. That is resolution. The correct is before the word" resolution" has to put extra space.

\section{5) Coda/reorientation}

Based on picture above, had shown that there is a missing space. That is coda/reorientation. The correct is before the word" coda/reorientation" has to put extra space.

\section{B. The students' perception of the types of students' errors in writing}

The Students' perception as the object of the research has to be known by themselves directly. Exactly, it is needed something as a way that can give more information about their problems. Interviewing will be conducted in this research to collecting the data. This research needs concrete interaction and giving the interview process flexibility to the students. So, this research uses an open guided interview. The result of the interview found that the perception is;

1. The first question: What do you feel when you are in the writing class?

Based on the interview relate to the first question the researcher can describe their feeling into four categories. They are, happy, bored, bored, and happy and nice.

\section{a. Happy}

Student A2

"I feel happy, because I can increase my idea and getting more vocabularies through English class.

\section{Student B2}

This statement also is supported by other student $\mathrm{B} 2$ who said "when we are in the writing class, the student of the class is happy, even though they are still lack of vocabularies and hard to understand"

\section{Student C2} lesson."

Student C2 also said "I feel really happy because English is my favorite

\section{Student B3}

\section{Student C3}

"I am happy because I can keep my process."

"I am happy because there : and games." 
IJRETAL

International Journal of Research on English Teaching and Applied Linguistics, Vol. 1, No.2, December 2020

Based on the result of the interview above, it can be known that there are five students feel happy, they are students A2, B2, C2, B3, and C3. Students A2 said that he feels happy because English can be a subject that can increase his knowledge and also improving vocabulary. It is different from students' B2, he said that his feeling is happy even though he still has a lack of vocabulary. Whereas, student $\mathrm{C} 2$, she is happy because she meets with her favorite lesson. Student B3 also happy because she wants to make progress through this subject and student C 3 is happy because there are music and also games. So, it can be concluded that one of the students' perceptions about their feeling when they are in writing class is happy, even though still have difficulties, such as lack of vocabulary and also really hard to understand. The situation of the class was active, the researcher saw that the students were happy when they got games from their teacher in the opening of the study.

\section{b. Bored}

One of the students' perceptions that they had considered when they were in the writing class, their feeling was bored. Here is the transcript of student A1 and A2;

\section{Student A1} material ,."

"When I learn English sometime I feel bored because just focused on giving the

\section{Student A2}

This statement also is supported by student A2 who said "I am bored when learn writing because the situation of the class is boring, we need some breaks like games".

Based on the statements of student A1 and A2 above, it can be known that they have the same feeling when in a writing class. Student A1 feels bored because the teacher it only focuses on giving the material, this statement also is supported by student A2, he said that he feels bored when the learning process, he thinks that why the teacher does not give us some breaks, such as games. Based on the statement before it can be concluded that the students sometimes feel bored because the teacher only focuses on giving material and nothing games.

\section{c. Happy but also bored}

\section{Student A3}

Student A3 said "I am happy but also bored, because I am just focused on giving the material and an assignment."

Based on what the researcher saw in the class about the students that feel happy and also bored only one student, she is student A3. He said that sometimes the student feels sleepy when and just focus on their business.

d. Nice

\section{Student A3}

Student A3 said that" I feel nice because it is very useful."

Based on the interview, Students A3 really enthusiastic to learn English because of the user for the future. 
IJRETAL

International Journal of Research on English Teaching and Applied Linguistics, Vol. 1, No.2, December 2020

2. The second question: Based on your opinion, is the first language influence in mastering the foreign language, can you mention three of the interferences in writing?

One of the students' perception was they considered that when they are in writing class, some special steps that had been done. Here is the transcript of enjoying, adapt with environment, very influence, The difficulties in using accent and also pronunciation, It does not give bad influence and can differentiate between the first language form and the second language form

\section{a. Enjoy}

\section{Student A1}

"I am enjoy."

Student B1

This statement also is supported by student B who said "I just enjoy, the lesson because I usually use English to speak since I was a child."

Based on the result of the interview above, student A1 feels enjoy English learning and student B1 also has the same feeling about English lessons because she has already used English when she was a child. So, it can be concluded that two of the students'perceptions about the influence of the first language related to the foreign language, they just enjoy because they have already used English to speak since they were a child and usually practice by using English in daily activity.

\section{b. Adapt to the environment}

Student C1

Student C1 said that "I just adapt to the environment".

Based on the interview of the interviewee, the students feel enjoy because student $\mathrm{C} 1$ thinks that it does not a problem for him, because he will always try to adapt to the environment.

\section{c. Very influence \\ Student A2 \\ "yes of course, it very influences me because we can not as like a native speaker".}

Based on the result of the interview to the interviewee above that Student A2 has got an influence, such as the difficulty to speak like with a native speaker.

\section{d. The difficulties in using accent and also pronunciation. Student B2}

This statement also is supported by student B2 who said "I have got difficulties in using accent and also pronunciation."

Based on the result of the interview show that student B2 has got difficult in how to use an accent and also pronunciation.

\section{e. It does not give bad influence \\ Student C2}

Student C2 said "It does not give bad influence because I have already used English since when I was a child."

Based on the result of the interview above, it can be concluded that the student C2's perception of the influence first language related to the second language is influence enough because as bilingual and has an accent is not like a native speaker. 
IJRETAL

International Journal of Research on English Teaching and Applied Linguistics, Vol. 1, No.2, December 2020

f. can differentiate between the first language form and the second language form A3 said" No, we can differentiate between the accent of Buginess as my the first language and the second language."

B3 said "No, I can differentiate the form of the first language and the second language."

C3 said" is not more give influence in my learning."

Based on the students'statement above, it can be understood that students A3, B3, and C3 had shown that they are enjoyed by their status as bilingual and they can be easy to differentiate between the first language with the second language.

2. The Third Question: Based on your experience what kinds of interferences that you have made on your writing?

One of the students'perceptions was they considered that when they were in writing class related to the kinds of interferences in writing. Here is the transcript of student $\mathrm{B} 2, \mathrm{C} 2$, and $\mathrm{A} 3$;

a. Grammar

Student B2

Studen B2 said "I always do mistakes in grammar, such as I feel confused in using to be(am, is are)".

\section{Student C2}

Student C2 said" that he always do mistakes in grammar."

\section{Student A3:}

" I always make a mistake in grammar as like, I made a sentence in simple past form but I use simple present form."

Based on the statements of students we can know that B2, C2, and A3 always make mistakes in grammar seems like when they want to make a history they still use a simple form, rather than use a simple past form.

\section{b. pronunciation}

\section{Student A1}

"I always make mistakes in pronunciation, such as has the use of a regular and irregular verb. Example Read (V1) red (V2) red (V3)".

Based on the interview above, it can be known that student A1 always do some mistakes such us, using incorrect grammar, irregular and regular verb.

\section{c. Grammar and tenses \\ Student B1}

B1 said "I also always make some mistakes when I am writing as like miss grammar and tenses".

Based on the interview above it can be concluded that student B1 always does miss grammar and tenses. Such us, making a story by using simple present rather than use simple past form. 
IJRETAL

International Journal of Research on English Teaching and Applied Linguistics, Vol. 1, No.2, December 2020

\section{d. Pronunciation and tenses Student C1}

Student C said "I always make mistakes in pronunciation and tenses. For Example, the pronunciation of "heart and hear".

Based on the interview above it can be concluded that student $\mathrm{C} 1$ always feels confused about using tenses in writing.

\section{e. Miss vocabulary and spelling word}

\section{Student A2}

Student A2 said "I always make some mistakes like miss vocabulary and spelling word for example; quiet and quite".

Based on the data of the interview by student A2 said that vocabulary and spelling are problems in writing.

\section{f. Spelling and pronunciation}

Student B3

Student B3 said" I make some mistake. Such as, in spelling and pronunciation such us quite and quiet."

Student B3 said that he has got difficulty in using spelling and pronunciation.

\section{g. Lack of vocabulary}

\section{Student C3}

Student C3 said "I still lack in vocabulary, do not master tenses and pronoun." Based on the interview, student $\mathrm{C} 3$ said that she still has difficulty in using tenses.

\section{The fourth question: What factors that cause you do interfere in writing?} The first students' perception

One of the students' perception was they considered that when they learned writing that influence by some factors, those are from statements A1, B1, and C1, A2, $\mathrm{B} 2, \mathrm{D} 2, \mathrm{C} 2, \mathrm{~B} 3$, and $\mathrm{C} 3$;

\section{a. Less knowledge}

\section{Student A1}

Student A said "that She still has less knowledge in English study".

Based on the data of the interview, it can be concluded that student A1 has difficulty in writing because he still has less knowledge.

\section{b. Seldom to practice}

\section{Students B1}

Student B1 said "that I seldom to practice in my daily activity".

Based on the data of the interview, it can be concluded that student B1 has got difficulty in writing because still seldom to practice.

\section{c. The influence of the environment}

\section{Student C1}

Student C1 said" that it influences by the environment". 
Based on the data of the interview, it can be concluded that student $\mathrm{C} 1$ always gets the influence from the outside and making her is not focus on her study.

\section{d. Forget the vocabulary}

Student A2

Student A2 said "that I always forget the vocabulary that I want to use in the sentence, miss auxiliary, and form."

Based on the data of the interview, it can be concluded that student A2 always gets the influence from the outside.

\section{e. Forget the form}

\section{Student B2}

Student B2 said"' that I always forget the form, less knowledge and can write but can not speak well".

Based on the data of the interview, it can be concluded that student B2 has got difficulty in writing caused less knowledge and forget the form.

\section{f. Do not practice a lot and the explaining of the teacher}

Student D2 said" I do not practice a lot and the explaining of the teacher is very fast and we need a game."

Based on the data interview, it can be concluded that student D2 has got the difficulty in writing caused does not understand with the teacher explanation.

\section{g. Do not understand the pattern and spelling word Student C2 \\ Student C2 said "that I do not understand the pattern and spelling word".}

Based on the interview, it can be concluded that student $\mathrm{C} 2$ has got difficulty in writing caused feel confused in using the spelling of the words.

\section{h. Do not practice and seldom to listening to the music}

Student B3 said" I do not practice and seldom listen to the music, feel bored in the class and I do not understand with the teacher's explaining."

Based on the data an interview, it can be concluded student B3 has got difficulty in writing caused the student needs something such as listening to music and the teacher explanation from unclear to be clear.

\section{i. Do not understand in grammar}

Student C3 said " I do not understand in grammar."

Based on the result of the interview above, it can be concluded that students C3's perception about the factor that makes him do interfere does not master tenses.

\section{The fifth question: What are your difficulties in writing?}

The students' perception was they considered that when they learned writing could be seen by how their understanding of the material and how they respond. Here is the transcript of student $\mathrm{A} 1, \mathrm{~B} 1, \mathrm{C} 1, \mathrm{~A} 2, \mathrm{~B} 2, \mathrm{C} 2, \mathrm{~A} 3, \mathrm{~B} 3$, and $\mathrm{C} 3$;

a. low in understanding about tenses, still have low vocabularies and the learning process does not effective 
IJRETAL

International Journal of Research on English Teaching and Applied Linguistics, Vol. 1, No.2, December 2020

\section{Student A1 to C1}

"We have some difficulties as like, low in understanding about tenses, still have low vocabularies and the learning process does not effective."

Based on the data of the interview, it can be concluded that the students A1 to $\mathrm{C} 1$ have gotten the difficulty in writing caused they still need time to improve their knowledge about tenses.

\section{b. feel confused in using vocabulary, spelling and conditional sentence}

\section{Student A2}

The student said" that I feel confused in using vocabulary, spelling, and conditional sentence."

Based on the data interview, it can be understood that student A2 still has difficulty to differentiate both of the components that the students had said before.

\section{c. less vocabulary and grammar}

\section{Student B2}

The Student said "that I still have less vocabulary and grammar."

Based on the data of the interview, it can be concluded that student B2 has got difficulty in writing caused still needs a process to learn grammar and improving vocabulary.

\section{d. Do not understand the pattern of tenses}

\section{Student C2}

The Student said" that I do not understand the pattern of tenses."

Based on the data of the interview, it can be concluded that student $\mathrm{C} 2$ has got difficulty in writing caused still need a process to learn more about tenses.

\section{e. Feel confused in using grammar \\ Student A3 said}

Student A3 said" I feel cc

$$
\text { using grammar." }
$$

Based on the data of the interview, it can be concluded that student A3 has got difficulty in writing caused feel confused in using grammar.

\section{f. Do not master tenses}

\section{Student B3}

Student B3 said" I do not master tenses."

Based on the data of the interview, it can be concluded that student B3 has got difficulty In writing caused his knowledge about tenses still low.

\section{g. Can not apply vocabulary in writing well \\ Student C3}

Student C3 said" I can not apply my vocabulary in writing well."

Based on the result of the interview above, it can be concluded that students $\mathrm{C} 3$ have some difficulties in writing, the majority of students still have difficulties in grammar and lack of vocabulary. 
IJRETAL

International Journal of Research on English Teaching and Applied Linguistics, Vol. 1, No.2, December 2020

\section{CONCLUSIONS}

Based on the result of the observation had found that there are four factors that make the students of the tenth grade of Athirah Bone do interfere in writing. The first is do not master spelling. The second is still confused about using the article. The third is Missing using singular and plural nouns. The last is missing space.

Based on the result of the interview had found that the students' perception of the types of students' errors in writing consists of five perceptions. The first is students' perceptions relate to the feeling. The second is students' perceptions relate with the first language' influence students in mastering the second language. The third is the students' perception relates to the students' experiences and kinds of interferences that students have made on writing. The fourth is the students' perception relates to the factors that cause students to do interfere in writing. The last is about the students' perception of the difficulties in writing. Based on those points consist of some categories. The first based on students' perceptions related to feeling include are happy, bored, happy but also bored, and nice. Whereas the second question about the first language' influence students in mastering the second language can conclude to be six categories. Those are enjoy, adapt to the environment, very influence, the difficulties in using accent and also pronunciation, it does not give an influence, and can differentiate between the first language from the second language from. The third, based on the students' experiences relate to kinds of interferences that students have made on writing can be categorized to be seven categories. Those are grammar, pronunciation, grammar and tenses, pronunciation and tenses, miss vocabulary and spelling word, spelling and pronunciation, and lack of vocabulary. The fourth is the students' perceptions of factors that cause students to do interfere in writing. it could be categorized to be nine factors. They are less knowledge, seldom to practice, the influence of the environment, forget the vocabulary, forget the form, do not practice a lot and the explaining of the teacher, do not understand the pattern and spelling word, do not practice and seldom to listening to the music, and do not understand in grammar. The last, based on the last question of the interview about the students' perception of the difficulties in writing had been categorized into seven perceptions. There are low in understanding about tenses, still have low vocabularies and the learning process does not effective, feel confused in using vocabulary, spelling and conditional sentence, less vocabulary and grammar, do not understand the pattern of tenses, feel confused in using grammar, do not master tenses, and cannot apply vocabulary in writing well.

\section{REFERENCES}

Bloomfileld, L,(1995). Language/Bahasa.PT gramadia Pustaka Utama, 1995), P.4.

Chaer,Abdul and Agustina Leonie, Sosiolinguistik:Perkenalan awal (Jakarta: Rineka Cipta, ,1995).P.158.

Corder, P. (1987). Error Analysis and Interlanguage. Oxford: Oxford University Press.

Dulay, H. (1982). Language Two. NewYork: Oxford University Press.

Ellis, Rod. (1997). Second Language Acquisition, New York: Oxford University Press, pp.1.

Hanna, Elias j, Learning English As a fourth language: The case of the Arab pupils in Israel, (Dissertation; Doctor of philosophy at Anglia Polytechnic University Faculty of Education,2009), P.3. Odlin, Terence, Language Transfer; Cross-Linguistic influence in second Language Learning(Cambridge University Pres,1997), P.3.

Harmer, Jeremy. (2007). How to Teach Writing , England: Longman

James, C. Error in Language learning and Use(London: Longman,1998).P. 12. 
IJRETAL

International Journal of Research on English Teaching and Applied Linguistics, Vol. 1, No.2, December 2020

Keith F. Punch, Introduction to Research Methods in Education (Singapore: SAGE, 2009), p. 174-175.

Lyons, John, New horizon in linguistics (Penguin book. 1997), P.4.

Maniam, Mahendran, the influence of first language grammar (11) on the English language (12) writing of Tamil school students: A case study from Malaysia. Dissertation.,2010), P.4.

Mayers, Alan. (2005). Gateways to Academic Writing: Effective Sentences, Paragraphs, and Essay, (New York: Longman.),p.1

Nababan, Sosiolinguistik (Jakarta:Grametika Pustaka Utama,1968).P.35.

Nunan, David. (1991). Language Teaching Methodology, New York: Book for Teachers PrenticeHall International (UK) Ltd.

Odlin, Terence, Language Transfer; Cross-Linguistic influence in second Language Learning(Cambridge University Pres ,1997),P.3.

Tarone, E, Interlanguage, (Journal volume 4, 2006), P.3.

Weinreich, Uril. Language in Contact (Mouton: The Hauge Paris, 1968).P.18. 